\title{
GREEN TOURISM SUPPLY CHAIN MANAGEMENT BASED ON LIFE CYCLE IMPACT ASSESSMENT
}

\author{
ALEXANDRA V. MICHAILIDOU*, CHRISTOS VLACHOKOSTAS, \\ CHARISIOS ACHILLAS, DIMITRA MALEKA, \\ NICOLAS MOUSSIOPOULOS, and ELENI FELEKI
}

\begin{abstract}
Laboratory of Heat Transfer and Environmental Engineering, Aristotle University of Thessaloniki, Thessaloniki, Greece
*Corresponding author: amichail@aix.meng.auth.gr
\end{abstract}

\begin{abstract}
Tourism is one of the most dynamic and far-reaching economic sectors in the world. Numerous different and complex activities are involved in the efficient development of tourism. These activities interrelate economic, environmental, social, cultural and political dimensions in the overall supply chain. However, apart from its key role as a driver of socio-economic progress, tourism is responsible for environmental deterioration, not only in areas popular with tourists, but also by enhancing climate change globally. This paper presents a robust method based on the Green Tourism Supply Chain Management (GTSCM) concept, which can be used to estimate the effect on the environment that can be attributed to each link of the supply chain. The overall approach is based on Life Cycle Impact Assessment (LCIA) theory and corresponding models. A case study to demonstrate the applicability of this approach is presented for two large seaside hotels located in Chalkidiki, Greece. Chalkidiki is the most popular tourist destination in Northern Greece. A LCIA questionnaire was developed and input data for the Life Cycle Assessment (LCA) obtained from the hotel managers. For this LCA SimaPro 8 software was used. The LCIA methods chosen were Eco-indicator 99 and CML 2001. The effect on fossil fuel consumption of both hotels due to their use of local transport and electricity was considerable but less than that needed for transporting the tourists by air to Chalkidiki. This paper clearly indicates that LCA and Life Cycle Thinking (LCT) can form the basis for promoting GTSCM in the tourism industry.
\end{abstract}

Keywords: Green Tourism Supply Chain Management, Life Cycle Assessment, Life Cycle Thinking, Eco-indicator 99, CML2001

doi: $10.14712 / 23361964.2016 .6$

\section{Introduction}

Over several decades, tourism has continued to grow and diversify and is currently one of the fastest growing economic sectors in the world (UNWTO 2015). According to the World Tourism Organization, currently the business volume of tourism equals or even surpasses that of oil exports, food products or automobiles. A highly competitive environment has forced tourism companies to adopt approaches already used in other industries such as manufacturing, agriculture, etc. in order to meet the needs of the most demanding customers. One of these is referred to as Tourism Supply Chain Management (TSCM), i.e. supply chain management in tourism-related companies.

According to Zhang et al. (2009), TSCM is defined as a network of tourism organizations engaged in different activities ranging from the supply of different components of tourism products/services, such as accommodation and flights, to the distribution and marketing of the final tourism product at a specific destination, and involves a wide range of participants in both private and public sectors. A typical tourism supply chain (TSC) involves the suppliers of all tourism goods and services that are delivered to the end-consumers (Tapper and Font 2004), as depicted in Fig. 1. The tourism product consists of three principal elements: accommodation, travel and recreational activities (Kuo and Chen 2009) and is perishable (cannot be stored for future use), with the complexity of the TSCM similar to that which manufacturing industry faces in producing and marketing their products (Page 2015; Ling 2015).

Apart from being important in determining socio-economic progress, tourism is responsible for the deterioration of the environment in tourist area (Gössling 2002). In response to the increasing concern of tourists about environmental issues, the tourism industry has switched to "green" in their supply chain (e.g. Budeanu 2009; Odoom 2012). For this reason, the concept of a Green Tourism Supply Chain Management (GTSCM) is promoted in the overall framework of tourism-related activities in order to consider its effect in terms of environmental deterioration and climate change, and initiatives to reduce its effect.

Various definitions of green supply chain management (GSCM) exist in the literature. According to Gilbert (2001), greening the supply chain is the process of incorporating environmental criteria or concerns into organizational purchasing decisions and long-term relationships with suppliers, whereas Zsidisin and Siferd (2001) define GSCM as "the set of SCM policies held, actions taken and relationships formed in response to concerns related to the natural environment with regard to the design, acquisition, production, distribution, use, re-use and disposal of the firm's goods and services". Seuring (2004) describes GSCM as the managerial 
integration of material and information flows throughout the supply chain to satisfy the demand of customers for green products and services produced by green processes. Srivastava (2007) defined GSCM as "integrating environmental thinking into supply chain management, including product design, material sourcing and selection, manufacturing processes, delivery of the final products to the consumers, and end-of-life management of the product after its useful life". According to Zhu et al. (2008), GSCM "ranges from green purchasing (GP) to integrated life-cycle management supply chains flowing from supplier, through to manufacturer, customer, and closing the loop with reverse logistics". GSCM covers the following activities: "green procurement", "green design", "green operations and reverse logistics", "green manufacturing" and waste management (Hervani et al. 2005). According to Walker et al. (2008), the green supply chain concept covers all phases of a product's life cycle, from the extraction of raw materials through the design, production and distribution phases, to the use of the product by consumers and its disposal at the end of the product's life.

The present study proposes a robust promotion of GTSCM, based on an estimate of the environmental effect that can be attributed to each link in the TSCM. The overall approach is based on Life Cycle Impact Assessment (LCIA) theory and corresponding models used for operating hotels and transport for tourist. It should be emphasized that hotels belong to the 1st level of suppliers of tourism products (Fig. 1) and are one of the most important agents of a "static" environmental burden in the TSCM (Michailidou et al. 2016). The lodging sector uses vast quantities of energy, water and products. Energy use per guest night can be as much as 98 MJ (Gössling 2002) and water consumption ranges between 84 and 24251 per guest-night (Gössling 2015). In addition, the lodging industry generates large volumes of waste. A typical guest generates at least $1 \mathrm{~kg}$ of solid waste per day (Davies and Cahill 2000), whereas a tourist from developed countries probably generates up to $2 \mathrm{~kg}$ per day in the United States (UNEP 2003). According to the literature, amongst other tourism environmental performance tools, Life Cycle Assessment (LCA) is crucial, since it evaluates environmental effects from different perspectives and based on different assumptions (e.g. Filimonau 2016). Furthermore, Life Cycle Thinking (LCT) can result in identifying the processes and/or flows that result in the highest consumption of resources and greatest environmental burden when attempting to estimate the total environmental effect. SimaPro 8 software is used to define the functional units, the boundaries and limitations of the problem under study. LCA and LCT form the basis for efficiently promoting GTSCM in the tourism industry.

This approach is demonstrated for the most popular tourism destination in Northern Greece, Chalkidiki. A comparative "environmental damage" analysis for two large hotels is produced and their respective contribution to the environmental burden is assessed. This approach results in a reliable assessment of damage that can be attributed to accommodating and transporting tourists.

\section{Materials and Methods}

TSC (Fig. 1) includes 1st and 2nd level suppliers, tour operators, travel agencies and tourists. 1st level suppliers includes tourism services providers, which directly supply tourism services to tourists or intermediaries (tour operators and travel agents) e.g. accommodation providers (e.g. hotels, camping sites, etc.), transport providers (e.g. renting cars, bus operators, etc.), food suppliers (e.g. restaurants), etc., whereas 2 nd level are those who directly supply tourism service providers with products or services, such as energy and water suppliers, food and drink manufactures, waste recycling and disposal services, etc. Travel agents retail tourism products and deal directly with tourists or via tour operators. Travel agents and tour operators can be the same business entities. It should be noted, that the TSC depends mainly on the characteristics of the Defined Area of Concentrated Tourism (DACT), i.e. the tourist destination. Addressing the environmental effect of TSCM at a tourism destination requires an environmental analysis of all of its components/products going back to the raw materials from which they were produced, through suppliers, suppliers' suppliers and so on.

In order to estimate the effects in the TSCM, LCA is carried out in four distinct phases (ISO-14040, ISO14044), as follows: (i) Goal and scope definition, (ii) Life cycle inventory (LCI), (iii) LCIA and (iv) Interpretation. LCIA attempts to establish linkages between the product or process and its potential environmental effects by addressing ecological and human health effects and resource depletion. The implementation of LCIA requires the LCI, which is an inventory of all input and output environmental flows of a product or service system (Frischknecht et al. 2007).

For LCI, a detailed list of all 1st and 2nd level suppliers, tourism operators and travel agents should be created. For each product or service for every supplier, materials and processes from "cradle-to-grave" should be identified in order to quantify the extraction of resources and emissions of a product system or process to air, water and land and their associated effects (Muthu 2014). This requires questionnaires to be appropriately designed and answered by managers/directors/engineers of each supplier during personal interviews. This is a demanding task, since it entails huge effort and availability of resources.

A number of effect assessment methods for quantifying the environmental performance of a product, process or service are available (JRC 2010). Inventory data is aggregated into specific environmental effect categories according to the selected LCIA. LCIA methods can be 
single-category (e.g. primary energy) or multi-category, with specific sets of effect categories. Multi-category LCIA methods can be problem-oriented or damage-oriented. An LCIA consists of 4 steps: (i) Classification, where all substances are sorted into classes according to the effect they have on the environment; (ii) Characterization, where all the substances are multiplied by a factor which reflects their relative contribution to the environmental effect; (iii) Normalization, where the quantified effect is compared to a certain reference value (e.g. the average environmental effect of a European citizen in one year); (iv) Weighting, where different value choices are given to effect categories to generate a single score.

Damage-oriented methods, such as the Eco-indicator 99 (Goedkoop and Spriensma 2001), model the cause-effect chain up to the endpoints, namely translate environmental effects into issues of concern such as human health, natural environment and natural resources. Three damage categories are distinguished: Human Health, Ecosystem Quality and Resources. Multiple endpoint indicators are combined in one single indicator measured in Eco-Indicator Points $(\mathrm{Pt})$ to provide a robust assessment. Endpoint indicators represent the consequences of negative environmental effects on humans and ecosystems and are the "endpoint" of a possible chain of causes and effects. Damage category level is normalized depending on the chosen perspective. In the hierarchist perspective (chosen in this study) the chosen time perspective is long-term and substances are included if there is a consensus regarding their effect. One of the advantages of Eco-indicator 99 is the single score output (expressed in $\mathrm{Pt}$ ) that enables a comparison of different components of a product/service or different products/services.
Problem-oriented methods, such as CML 2001 (JRC 2010), have midpoint effect categories and relevant indicators to model cases at an early stage in the cause-effect chain, namely translate effects into environmental themes such as climate change, acidification, human toxicity, etc., which allows a transparent assessment. This means that CLM indicators aggregate data on emissions (the starting points in the cause-effect chain) to potential effects in various categories (e.g. global warming, acidification, etc.), but do not assess the endpoints, such as the loss in terms of biodiversity, damage to human health, etc., caused by these effects (WRAP 2008). Each effect category is characterized by a midpoint indicator, which uses a defined reference substance in order to quantify the effect of a classified emission in relation to the reference substance. The CML method has different sets of normalization. The step of normalization calculates the magnitude of the effect category on the investigated system in relation to reference information (Guinée et al. 2002). CML provides detailed information about several environmental effect categories. The Global Warming Potential (GWP100) indicator, expressed in $\mathrm{kg}$ of $\mathrm{CO}_{2}$-eq., is the indicator used from CML 2001, which is closely correlated with energy use (Blengini 2009), and is a measure of the Greenhouse Effect according to IPCC.

LCA implementation can be facilitated using relevant software and its corresponding effect assessment methods. In any case, the functional unit, boundary selection and limitations must be defined. It should be emphasized that the appropriate functional unit for LCA services within the hotel sector is more difficult to define than any other industry. The most common functional units used in similar studies are one "guest night" (Filimonau et al. 2011) , e.g. a night spent by one tourist in one ac-

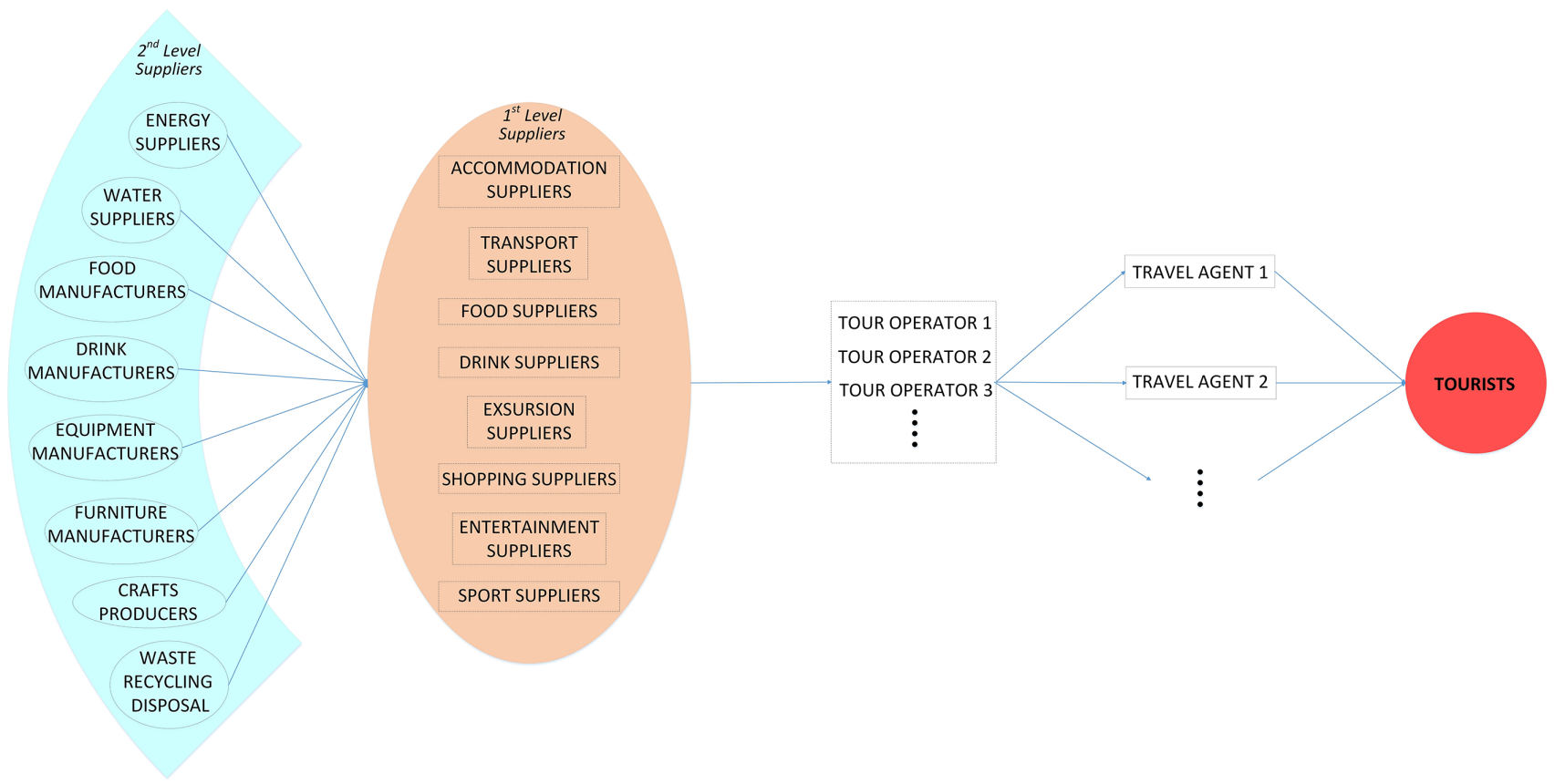

Fig. 1 Links in the overall TSC related to activities inbound/outbound in a DACT. 
commodation building, and 1 week of a holiday including transport services to reach and leave the destination (Michailidou et al. 2016).

\section{Case Study}

The selected DACT for implementation of the proposed approach is Chalkidiki, a large peninsula in Central Macedonia with the longest coastline (550 kilometers) of all land prefectures in Greece. The nearest airport to Chalkidiki is the International Airport "Makedonia", close to the city of Thessaloniki. Chalkidiki has $5111-5$ star hotels, with a total of 44,579 beds, which is approximately $5 \%$ of the hotels nationally. With a total surface area of 2,900 $\mathrm{km}^{2}$ and a population of 105,908 inhabitants in 2011, the number of international tourists was over 523,000 in 2012 (EL.STAT. 2014), which approximates to a $500 \%$ increase in population. In $2012,80 \%$ of all tourists visiting Chalkidiki were international tourists, $49.2 \%$ of which came from 27 countries (excluding Greece) in the European Union (EU) and 49.6\% from the rest of Europe (including Russia and Turkey). 34.2\% of the tourists visiting Chalkidiki came from the Balkans and Romania, whereas tourists from Russia exceeded $27 \%$. The area is characterized by high "tourism flows" compared to the permanent residents, and numerous agents of "dynamic" environmental burden, especially transport for reaching and leaving the destination and for recreational purposes.

After the selection of DACT, hotels were selected as the 1st level suppliers to be studied. In an effort to promote LCT principles and approach hotel managers in the area, a questionnaire was prepared. A pre-test procedure was conducted in order to assess the comprehensibility of the "draft" questionnaire and the probable effectiveness of extracting data from managers/directors/engineers. Essential introductory information was provided to the interviewees synoptically combined with a brief description of the principles of LCT and LCA, and managers gave their input regarding questionnaire's content based on their expertise. They participated in the process for establishing the main components in the implementation of the results of the LCA. Furthermore, they emphasized the need to keep the questionnaire simple and comprehensible. The pilot-study revealed that all hotel managers understood the input required. After making the appropriate modifications and improvements, the final questionnaire was produced.

For the case studied, SimaPro 8 software was used. The LCIA methods chosen are Eco-indicator 99 and CML 2001. The functional unit of the system studied is defined as one week of a holiday including transport services to reach and leave the destination. The system boundary is regarded as the operational use of a hotel including water and energy consumption for: (i) HVAC systems, (ii) production of hot water, (iii) lighting, (iv) kitchen opera- tion, e.g. cooking appliances, refrigerators, freezers, etc., (v) laundry facilities and (vi) other electrical devices e.g. TV's, refrigerators in rooms, cleaning devices, and elevators. The transport of tourists from their original place to the hotel and their return is also taken into account. Waste generation is excluded from this study since the hotels studied did not keep such records, which is typical of the area studied. Two seaside large-sized hotels were examined in the area studied. The characteristics of each hotel are presented in Table 1.

Table 1 Characteristics of the two hotels studied in Chalkidiki (Reference year 2013).

\begin{tabular}{|l|l|l|}
\hline & Hotel 1 (5*) & Hotel 2 (3*) \\
\hline Location & Sithonia & Kassandra \\
\hline No of Rooms/Beds & $202 / 500$ & $151 / 400$ \\
\hline No of floors & 2 & 2 \\
\hline Surface area & $15,000 \mathrm{~m}^{2}$ & $5,936 \mathrm{~m}^{2}$ \\
\hline Seasonal operation & 6 months & 6 months \\
\hline Occupancy rate & $92 \%$ & $94 \%$ \\
\hline $\begin{array}{l}\text { Type of building } \\
\text { construction }\end{array}$ & separate standing & separate standing \\
\hline Distance from airport & $100 \mathrm{~km}$ & 102 km \\
\hline Fuel for Heating & Diesel & Gas \\
\hline $\begin{array}{l}\text { Fuel for Air Condi- } \\
\text { tioning }\end{array}$ & Electricity & Electricity \\
\hline Fuel for Hot Water & Diesel & Gas \\
\hline $\begin{array}{l}\text { Facilities \& services } \\
\text { offered }\end{array}$ & $\begin{array}{l}3 \text { swimming pools, } \\
\text { spa, } 2 \text { conference } \\
\text { rooms }\end{array}$ & $\begin{array}{l}2 \text { swimming pools, } \\
\text { tennis, basketball } \\
\& \text { volley courts }\end{array}$ \\
\hline Laundry & Yes & Yes \\
\hline In-house restaurant & $\begin{array}{l}2 \text { restaurants, bar, } \\
\text { beach bar }\end{array}$ & 1 restaurant, 2 bars \\
\hline Year of construction & 2007 & 1991 \\
\hline
\end{tabular}

According to EL.STAT. (2014), 65\% of international tourists in 2012 travelled by airplane to the International Airport "Makedonia" in Thessaloniki and then reached their hotel by coach or car. The remaining $35 \%$ of international tourists came from the Balkan Area and mainly came by car. For the road transport analysis, a petrol car EURO 4 with average occupancy of 3 passengers is assumed for tourists coming from the Balkans, whereas for the other tourists it is a coach for their transport from the airport and back. Flight distances from major airports near the capital of each country to International Airport "Makedonia" were calculated.

\section{Results and Discussion}

A fully detailed "network of activities" for each hotel was created in order to assess their overall environmental burden for two cases: (a) transport of tourists was not taken into account and (b) transport was taken into ac- 


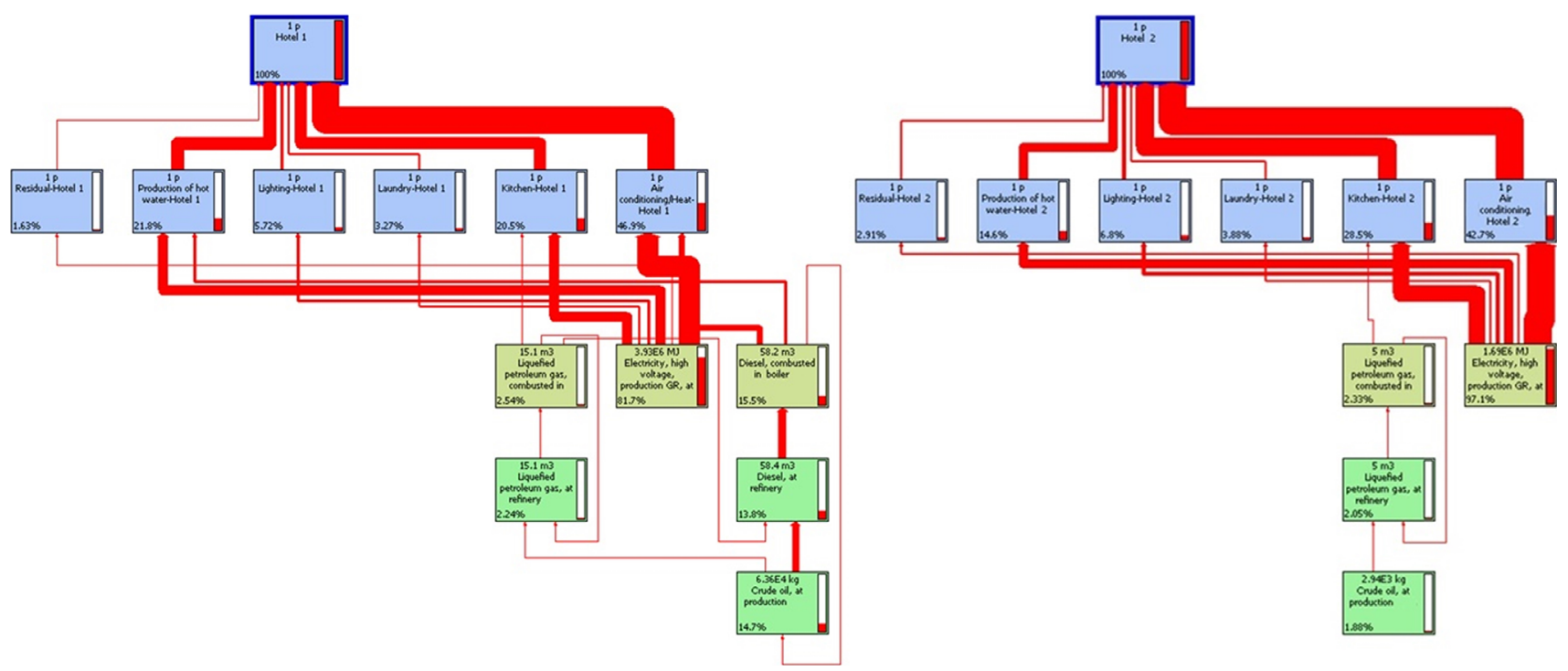

Fig. 2 Overview of the processes networks for hotels 1 and 2 generated in SimaPro 8.

count (Fig. 2). According to Eco-Indicator 99 effect assessment method for case (a), the operational use of hotel 1 resulted in greater environmental damage than that of hotel 2 (Fig. 3). When transport is included in the LCIA (case (b)), transport is responsible for the biggest share of the total environmental damage for both hotels. In addition, a comparative analysis of travel services in the case studied demonstrates that air transport has the highest absolute effect on all three categories of endpoints of Eco-indicator 99 (Resources, Ecosystem Quality, Human Health) compared to road transport. This finding is in line with the results of other similar studies, that airplanes are the most carbon intense means of transport (e.g. Filimonau et al. 2014).

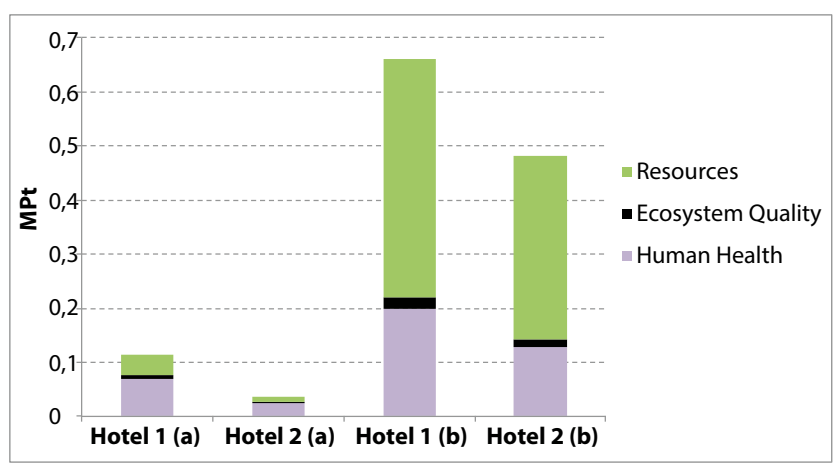

Fig. 3 Evaluation of the effect of both hotels in terms of (a) operational use and (b) operational use, air and road transport, with Eco-indicator 99, expressed in MPt $\left(=10^{6} \mathrm{Pt}\right)$.

When the operational phase of hotels is considered in isolation, HVAC systems are the biggest energy users in all cases, followed by kitchen facilities and the production of hot water. This is characteristic of all-sizes of hotels in Chalkidiki as solar energy, surprisingly, is not widely exploited in this area. Thus, most of the environmental loads of a hotels' operation arises from fossil fuel consumption (especially from lignite-based electricity). Based on these results, policy making should primarily put forward incentives for maximizing the use of Renewable Energy Sources (RES) by hotels in this area. Measures such as the use of energy-efficient lights in tourist lodgings, solar water heating systems and HVAC and lighting automation systems need to be promoted in order to minimize the overall environmental effect attributed to tourism in Chalkidiki. External wall insulation is also another important measure for saving energy especially for hotels that are more than 20 years old. These options highlight the need for central government initiatives to provide economic instruments and financial motives for both local authorities and tourism enterprises. These measures are easy to implement, have significant environmental benefit in relation to their cost and are socially very acceptable.

Fig. 4 illustrates the results of midpoint effect category scores for the two hotels, including transport. The effect on fossil fuel consumption is the highest for both hotels due to transport activities and use of conventional lignite electricity. Respiratory inorganics follow in terms of ranking of their effects relative to fossil fuel consumption. Effects on respiratory organics, radiation and ozone layer are negligible and are not presented in Fig. 4. The analysis demonstrates that hotel 1 is responsible for the largest share in terms of all 11 effect categories of Eco-indicator 99.

The effect assessment method CML 2001 was used to determine the midpoint effect category of Global Warming Potential over a period of 100 years (GWP100). Hotel 1 is responsible for the highest $\mathrm{CO}_{2}$-eq. emissions (Fig. 5). Although both hotels are approximately the same distance from the airport, the difference in $\mathrm{CO}_{2}-$ eq. emissions is due to the different number of international tourists. A comparative analysis of travel scenarios demonstrates that air transport has the highest effect on 
all three categories of endpoints of Eco-indicator 99. This is in line with the results of other studies, that airplanes are the most carbon intense means of transport (e.g. Peeters and Schouten 2006).

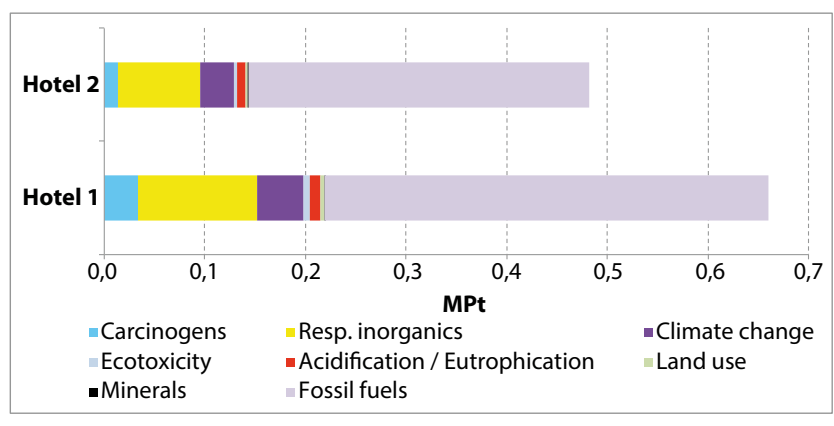

Fig. 4 Results of the effect category scores of Eco-indicator 99 for both hotels including transport.

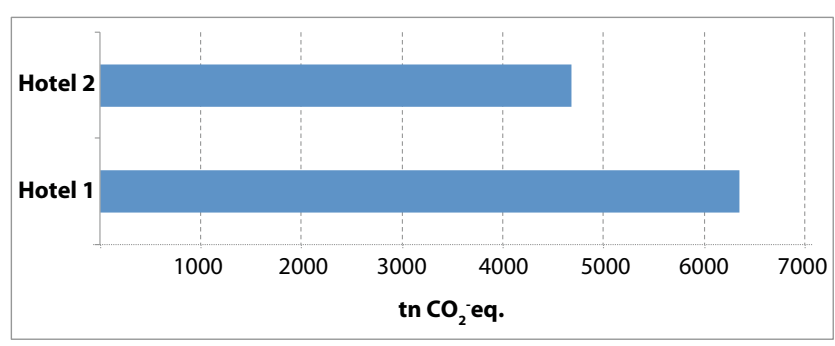

Fig. 5 100-year projection of the global warming potentials (GWP) in terms of $\mathrm{CO}_{2}$ for each hotel.

\section{Limitations}

Although it is well established that the TSCM includes many components, accommodation and transport are the central factors of tourism, since they influence tourists' choices (Guo and He 2012). On this basis, this study initially was planned to gather data from all the suppliers of each hotel, whose manager agreed to participate, in order to assess the environmental effects of the TSCM of a DACT. Unfortunately, most of the owners or managers of the large hotels refused to participate in this study because they were not free to do so or feared the lack of confidentiality, despite written assurance from the researchers. In addition, most of them claimed they could not provide us with data regarding their suppliers without their consent. Collecting information from each supplier of each hotel is a difficult task. On the other hand, the majority of small hotels in Chalkidiki do not keep detailed records of their resource consumption. These are the reasons for restricting the study to the suppliers of energy and water to the hotels and transport for tourists.

Hotels with ecolabels and EMS certification facilitate the task of data collection for the LCIA, since they keep up to date records. It should be noted that hotel 1 has been awarded a Green Key. Large-sized hotels are more willing to adopt environmental management schemes in order to ensure that their services and products are environmental-friendly, since they possess the capacity and resources and have the ability to draw on appropriate expertise to introduce environmental protection measures (Ayuso 2007). To this end, large-sized hotels need to ascertain whether every component of the services they offer and products they buy from their suppliers are environmental-friendly, forcing suppliers/companies to engage with their downstream supply chain towards the consumer and their upstream chain towards producers. Large-sized hotels incorporate environmental awareness and efficiency as a product quality issue for their suppliers (Fond et al. 2008).

\section{Conclusions}

This paper clearly indicates that LCIA can form the basis for efficiently promoting GTSCM. The corresponding measures and strategies for tourism are driven mainly by industry's desire to reduce the risk of a negative public image and increase prospective organizational benefits (Budeanu 2009). The fundamental principle of GTSCM rests on collaboration between companies and their suppliers, and their willingness to link their aims and essential operational processes to create unique, international, market satisfying resources that will satisfy their customers and help them gain a competitive advantage. Through collaborative research and development, companies can develop more innovative, environmental products and services of higher quality with the assistance of their suppliers (Tan 2002).

Hotels are highly interdependent with other businesses, which provides a unique opportunity to encourage their partners to help them to attain their environmental mission (Lakshmi 2002). As hotel companies manage and operate their properties, they should focus on several aspects, such as logistics management, inventory management, information technology, procurement and distribution, lean and green supply chain practices. Focusing on the logistics and supply chain of an organization's operations has helped a wide variety of industries become logistic powerhouses as part of their operations performance. If applied properly by the hotel industry to improve efficiencies and reduce costs, hotel companies will not only save money, but also contribute to the greening of TSCM.

The accommodation sector is only a part of the TSC, all members/parts should manage their activities by considering their links with climate change and reducing their carbon-footprint, by taking into account the whole chain. Hotels should be very careful about their environmental management since unconscious and unplanned practices can cause weaknesses in the whole GSCM. The hospitality sector may also benefit from applying some of the lessons learned from the application of GSCM practices in manufacturing and other sectors. The collection 
of data across the supply chain of these two hotels and other hotels in the area is definitely a challenge for the future if the environmental loads and greenhouse gas emissions of the whole TSCM are to be assessed and specific recommendations for minimizing environmental loads and greenhouse gas emissions proposed.

\section{REFERENCES}

Ayuso S (2007) Comparing voluntary policy instruments for sustainable tourism: The experience of the Spanish hotel sector. J Sustain Tour 15: 144-159.

Blengini GA (2009) Life cycle of buildings, demolition and recycling potential: a case study in Turin, Italy. Build and Environ 44: 319-330.

Budeanu A (2009) Environmental supply chain management in tourism: The case of large tour operators. J Clean Prod 17: 1385-1392.

Davies T, Cahill S (2000) Environmental Implications of the Tourism Industry. Resources for the Future, Washington DC.

EL.STAT. (2014) Official webpage http://www.statistics.gr (Accessed 22 July 2015).

Filimonau V (2016) Life cycle assessment (LCA) and life cycle analysis in tourism: A critical review of applications and implications. Springer International Publishing.

Filimonau V, Dickinson J, Robbins D (2014) The Carbon Impact of Short-haul Tourism: A Case Study of UK Travel to Southern France Using Life Cycle Analysis. J Clean Prod 64: 628-638.

Filimonau V, Dickinson J, Robbins D, Huijbregts MAJ (2011) Reviewing the carbon footprint analysis of hotels: Life Cycle Energy Analysis (LCEA) as a holistic method for carbon impact appraisal of tourist accommodation. J Clean Prod 19: 1917-1930.

Font X, Tapper R, Schwartz K, Kornilaki M (2008) Sustainable supply chain management in tourism. Bus Strat Env 17: 260-271.

Frischknecht R, Jungbluth N, Althaus H-J, Doka G, Dones R, Hellweg S, Hischier R, Humbert S, Margni M, Nemecek T (2007) Implementation of Life Cycle Impact Assessment Methods; Final report ecoinvent v2.0 No. 3. Swiss Centre for Life Cycle Inventories.

Gilbert S (2001) Greening supply chain: enhancing competitiveness through green productivity. Report of the Top Forum on Enhancing Competitiveness through Green Productivity held in the Republic of China, 25-27 May.

Goedkoop M, Spriensma R (2001) The Eco-indicator 99. A damage oriented method for Life Cycle Impact Assessment. Methodology Report, PRé Consultants, The Netherlands.

Gössling S (2015) New performance indicators for water management in tourism. Tourism manage 46: 233-244.

Gössling S (2002) Global environmental consequences of tourism. Global Environ Chang 12: 283-302.

Guinée JB, Gorrée M, Heijungs R, Huppes G, Kleijn R, Koning A, Oers L. van, Wegener Sleeswijk A, Suh, S, Udo de Haes HA, Bruijn H de, Duin, R. van, Huijbregts MAJ (2002) Handbook on life cycle assessment. Operational guide to the ISO standards. I: LCA in perspective. IIa: Guide. IIb: Operational annex. III: Scientific background. Kluwer Academic Publishers, Dordrecht, 2002.
Guo X, He L (2012) Tourism supply-chain coordination: the cooperation between tourism hotel and tour operator. Tourism Econ 18: 1361-1376.

Hervani AA, Helms MM, Sarkis J (2005) Performance measurement for green supply chain management. Benchmark Int J 12: $330-353$.

JRC (2010) ILCD Handbook: Analysing of existing Environmental Impact Assessment methodologies for use in Life Cycle Assessment. European Commission Joint Research Centre (JRC).

Kuo N-W, Chen P-H (2009) Quantifying energy use, carbon dioxide emission, and other environmental loads from island tourism based on a life cycle assessment approach. J Clean Prod 17: 1324-1330.

Lakshmi DKV (2002) Environmental Management System ISO 14001 in hotel industry.

Ling R (2015) A review of Tourism Supply Chain based on the Perspective of sustainable development. J Econ Sustain Develop 6: $128-132$

Michailidou AV, Vlachokostas C, Moussiopoulos N, Maleka D (2016) Life Cycle Thinking used for assessing the environmental impacts of tourism activity for a Greek tourism destination. J Clean Prod 111: 499-510.

Muthu S (2014) Assessing the Environmental Impact of Textiles and the Clothing Supply Chain. Woodhead Publishing.

Page SJ (2015) Tourism Management (5th Edition), Routledge, Taylor and Francis Group, London and New York.

Peeters P, Schouten F (2006) Reducing the ecological footprint of inbound tourism and transport to Amsterdam. J Sustain Tour 14: $157-171$.

Odoom CK (2012) Logistics and Supply Chain Management in the Hotel Industry: Impact on Hotel Performance in Service Delivery. UNLV Theses/Dissertations/Professional Papers/Capstones. Paper 1339.

Seuring S (2004) Industrial ecology, life cycles, supply chains: differences and interrelations. Bus Strat Environ 13: 306-19.

Srivastava KS (2007) Green supply-chain management: a state-ofthe-art literature review. Int J Manag Rev 9: 53-80.

Tan K (2002) Supply chain management: practices, concerns and performance issues. The J Supply Chain Manage 38: 42-53.

Tapper R, Font X (2004) Tourism supply chains: Report of a desk research project for the travel foundation. Leeds Metropolitan University, Environment Business and Development Group, Leeds, UK.

UNEP (2003) A manual for water and waste management: what the tourism industry can do to improve its performance.

UNWTO (2015) Official webpage http://www2.unwto.org (Accessed 22 July 2015).

Walker H, Di Sisto L, McBain D (2008) Drivers and barriers to environmental supply chain management practices: lessons from the public and private sectors. J Purch Supply Manag 14: 69-85.

WRAP (2008) LCA of Management Options for Mixed Waste Plastics, final report, June 2008, WRAP.

Zhang X, Song H, Huang GQ (2009) Tourism supply chain management: A new research agenda. Tourism Manage 30: 345-358.

Zhu Q, Sarkis J, Lai KH (2008) Green supply chain management implications for closing the loop. Transport Res E-Log 44: 1-18.

Zsidisin GA, Siferd SP (2001) Environmental purchasing: a framework for theory development. Eur J Purch Supply Manag 7: 61-73. 